\title{
The aesthetics of the eyes and mouth position in a three-point face schema
}

\author{
Waldemar Frackiewicz
}

\begin{abstract}
Laboratory of Audiovisual Didactic Aids at the Faculty of Pedagogics and Psychology, Maria Curie-Skłodowska University, Narutowicza 12, 20-004 Lublin; E-mail: frawe@sokrates.umcs.lublin.pl
\end{abstract}

\begin{abstract}
Oculographical research of people watching a human face indicates that beholder's eyes stop most often and for the longest period of time on the eyes and the mouth of the face looked at and that they move among these three points most frequently. The position of the eyes and mouth in relation to one another can be described with a single number being a measure of an angle with the vertex in the middle of the mouth and with arms crossing the centers of the eye pupils. The angles were measured from photographs of people from all over the world, as well as of residents of Lublin. Subsequently, the subjects from Lublin were asked to make face schemas by positioning the eyes and the mouth in the way they considered most attractive. The eye-mouth-eye angle of these schemas was measured. Additionally, measurements of the same angle were taken from the faces depicted on icons. The schemas of the most attractive - according to the subjects - faces were characterized by angles approximating the mean angle from the photographs, and significantly greater than the mean angle from the icons.
\end{abstract}

KEY WORDS face features, eye-mouth-eye angle, attractiveness, photograph, icon

Prz. Antropol. - Anthropol. Rev. (2001), vol. 64, pp. 93-100, Fig. 1, Table 1. ISBN 8386969-64-4, ISSN 0033-2003

\section{Introduction}

Appreciation of beauty has been peculiar to man for millennia, but scientific human beauty research developed intensively only in the last decades of the 20th century. A substantial part of studies in this field deal with the visual aspect of the issue. In interpersonal contacts we devote most of our attention to the face. As far as aesthetic preferences are concerned, both universal patterns and racial, ethnic and sex differences are observed.

A general statement to the effect that we find or do not find someone attractive can be conditioned by many factors. Women, for example, prefer different male faces depending on the phase of their menstrual cycle [PENTON-VOAK et 
al. 1999]. Scientific research indicates that women tend to choose to work with people bearing resemblance to them, and that they tend to perceive women similar to them as the most feminine. Such relations were not observed in men [FRĄCKIEWICZ 1998]. However, a connection of preferences with parental face patterns was noticed. This applies to some animals [KENDRICK et al. 1998] as well as to people. FRACKIEWICZ [2000] showed that subjects (irrespective of their sex) prefer to cooperate with persons resembling their mother rather than the father. According to KONNER [1982] the primary adaptive interest in faces stemmed from a need to determine kinship.

SYMONS claims [1979] that the model of attractiveness is based on an "inner image" which forms in the human brain as a result of the averaging of all faces one has seen. There are also studies, which indicate that apart from having the inborn face averaging system, we can also be born with a phylogenetically formed model of attractiveness. Threeand six-month-old babies spend longer looking at slides showing faces regarded as attractive by adults than at unattractive ones [ETCOFF 2000].

Studies on attractiveness, based on photographic or computer-averaged pictures of faces, do not give any conclusive explanation on the origin of the averaged facial model in our preferences. In the behavior of an animal choosing a partner there can be a preference for the average as it is indicative of proper body build and good health [KOESLAG 1990]. Some features situated on the edges of their distribution can be also perceived as attractive, e.g., big antlers in deer or tail in a peacock can be a sign of good health, while in man the same may apply for instance to the shape of the mouth and the spacing and the size of the eyes in a female face in the so-called "child schema" [EIBLEIBESFELDT 1987]. Similarly, it happens that individuals with exaggerated, abnormal, pathological or rare features are preferred [LORENZ 1943; EIBLEIBESFELDT 1986; DRÖSCHER 1982]. Abnormal schemas of the child's head (similar to those in children with hydrocephaly) were preferred more often than normal ones (especially by women) [HÜCKSTED 1965]. "Hyperfemale" faces turned out to be more attractive for men than average ones [HIRUKAWA and YAMAGUCHI 1996], while "hypermale" faces were found less attractive both by men and by women [ETCOFF 2000].

Face elements, which may be "key stimuli" triggering certain "release mechanisms", e.g., aesthetic preferences, can be found by analyzing the eyeball movements during the perception of a face. A two-month-old baby concentrates on the eyes and the mouth when it notices a face [FRIDLUND 1994]. A specific fixation of the eyes on the eyes and the mouth of the face looked at as well as frequent eye movements among these three points on the face were noticed while examining adults' eyeballs movement by means of an oculograph [CARON et al. 1973; GIBSON 1969; YARBUS 1965; ZUSNE 1970]. Fixations and the eye movement trajectories can indicate not only the importance of certain face elements, but also the importance of their position in relation to one another. Displacement of the eyes and the mouth in pictures of faces results in a reduction of perception task indicators [HAIG 1984]. VLEK and HEIJDEN [1979] were analyzing the perception of the 
resemblance of faces on photographs (subjects indicated their belonging to one of two families) by manipulating the position of the eyes only. The correct situation of facial elements enables good recognition, even if these elements are replaced with e.g., geometrical figures or other patterns [DAVIDOFF 1986]. Two painted spots positioned next to each other draw more attention than one or three spots. Moreover, the impression is even stronger when they are situated horizontally rather than vertically or diagonally [Coss 1968]. Symmetrical patterns are recognized easier and remembered better than non-symmetrical ones [DERĘGOWSKI 1990].

Can the very position of the eyes and the mouth in relation to one another be valued from the aesthetical point of view? What is the distribution of the arrangement of these elements in real faces?

\section{Course of the experiment}

The position of the eyes and the mouth in relation to one another (irrespective of the size of the face or its image) can be described explicitly by the measurement of the angle with the vertex in the middle of the mouth and the arms crossing the centers of the pupils. This angle has been measured in this study by means of a protractor with $1^{\circ}$ accuracy.

\section{Analysis of published photographs}

In order to estimate the abovementioned angle in humans, the author measured 218 faces (109 female and 109 male ones) of different age and nationality people from all over the world. Neither the exact age, nor the geographical-population composition of the sample were checked. The measurements were taken from frontal view photographs of the faces published in anthropological, ethnographical or other magazines. A non-anthropometric photograph was qualified as showing a frontal view of a face based on the author's own experience as a portraitpainter and photographer. The elements indicative of a rotation of the head around the vertical axis are as follows: different visibility of the left and right ear, the asymmetry of the view of the nose and the position of the eyes. The rotation around the horizontal axis is indicated by a change in the visibility of the chin, lips, nostrils, eyebrows, and the upper part of the head, as well as by the context of the background. Rotated or tilted faces were excluded from the study. The distributions of variation of the angle under examination for women and for men separately are shown in Figure 1A; the distribution parameters are shown in the first line of Table 1.

Table 1. Statistical characteristics of the eye-mouth-eye angle for women and men in each group under examination

\begin{tabular}{|c|c|c|c|c|c|c|c|c|c|c|}
\hline \multirow{2}{*}{ Faces } & \multicolumn{5}{|c|}{ Women } & \multicolumn{5}{|c|}{ Men } \\
\hline & $n$ & mean & median & $s d$ & $\min -\max$ & $n$ & mean & median & $s d$ & $\min -\max$ \\
\hline 1. from the world & 109 & $48.9^{*}$ & 48.0 & 3.19 & $41-57$ & 109 & 47.3 & 47.0 & 3.70 & $38-56$ \\
\hline 2. from Lublin & 64 & 48.8 & 49.0 & 2.62 & $42-54$ & 59 & 48.0 & 48.0 & 3.15 & $42-57$ \\
\hline 3. created by & 64 & 46.6 & 48.0 & 6.70 & $31-66$ & 59 & 48.5 & 50.0 & 7.72 & $32-66$ \\
\hline 4. from icons & 10 & 44.3 & 43.5 & 4.52 & $38-52$ & 62 & 44.1 & 43.0 & 4.61 & $35-55$ \\
\hline
\end{tabular}

* Significant intersexual difference $(\mathrm{p}<0.01)$. 


\section{Experimental group}

In 1997, the present author examined 123 adult Polish residents of Lublin (64 women, 59 men) aged 19-68 years. Most of them were 21-year-olds, and their mean age (for men and women) was 25 years. Most of the subjects were pedagogy or archeology students (89 people), the second largest group were people with academic education (29), the smallest number of the subjects had secondary or basic education (5 people). I took the frontal view photos of these people's faces (from a distance of $1 \mathrm{~m}$, using a $58-\mathrm{mm}$ focal-distance lens, with the optical axis perpendicular to the face plane). Measurements of the eyes and mouth positions were taken from the pictures' negatives displayed with an enlarger. The distributions of the variation of the angle under examination in women and in men are shown in Figure 1B; the distribution parameters are shown in Table 1.

\section{Analysis of the face schemas' preferences}

The subjects referred to in the preceding paragraph were given 3 black discs with a diameter of $15.5 \mathrm{~mm}$, an A4 sheet of paper and instructions to use the discs to make a schema of a face, consisting of the eyes and the mouth, they find the most attractive. The sheets of paper they had received depicted a face with blurred contours (light colored face against the dark background) to make the determining of its shape and size impossible, but with a distinctly marked lowest point of the chin.

The distributions of variation of the eye-mouth-eye angle determined by the centers of the discs on the facial sche- mas created by men and by women are shown in Figure 1C; the distribution parameters are shown in Table 1.

\section{Analysis of the icon faces}

Aesthetic preferences of the threepoint face schema can be also observed in painting. These already historical preferences were examined in icons. The choice of icons rather than other forms of face representations was made because icons usually show the face in its frontal view, their purpose is contemplation (an equivalent of a face to face meeting) and to viewer's attention. Icons were usually created in a state of concentration conducive to projection of deeply conditioned aesthetic preferences. Measurements of the angle were taken from 74 icon reproductions printed in a number of publications [ALPATOV 1970; ANTONOVA 1966; BREMSKE 1988; BULKIN 1982; ROZANOVA 1970; SALKO 1978; VORONIN 1977]. They depicted faces of 62 men, 10 women and 2 angels. The distributions of variation of the angles measured on the faces depicted in these icons are shown in Figure 1D; the distribution parameters are presented in Table 1.

\section{Results and discussion}

The eye-mouth-eye angle measured in the pictures of people from all over the world proved to be significantly $(\mathrm{p}<0.001)$ larger in women $(\mathrm{a}$ mean of $48.9^{\circ}$ ) than in men (a mean of $47.3^{\circ}$ ), and comparable with the respective values of the angles measured in the photographs of the people from the experimental group (insignificant differences, $\mathrm{p}>0.05)($ see Table 1$)$. 


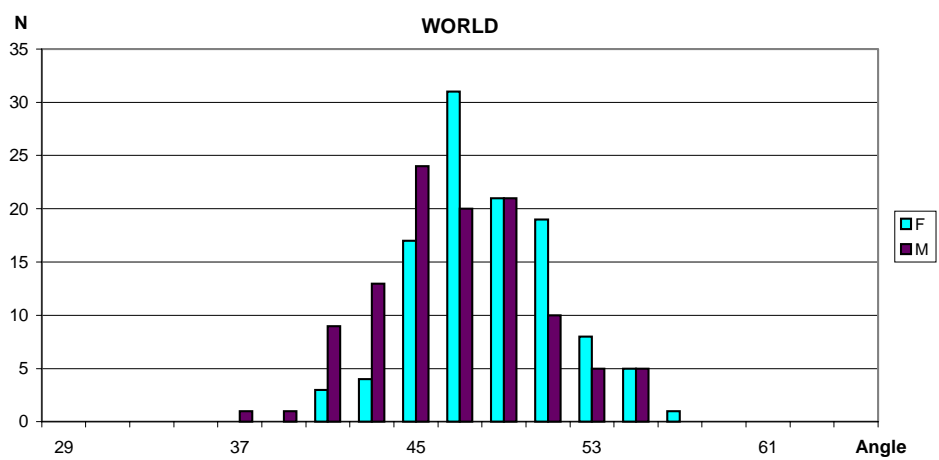

A

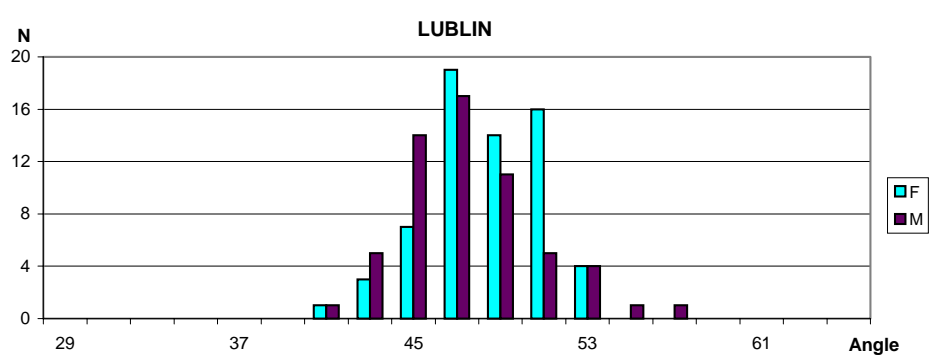

B

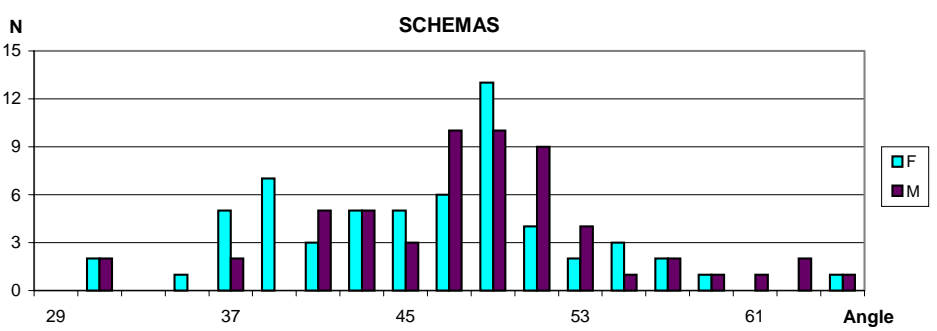

C

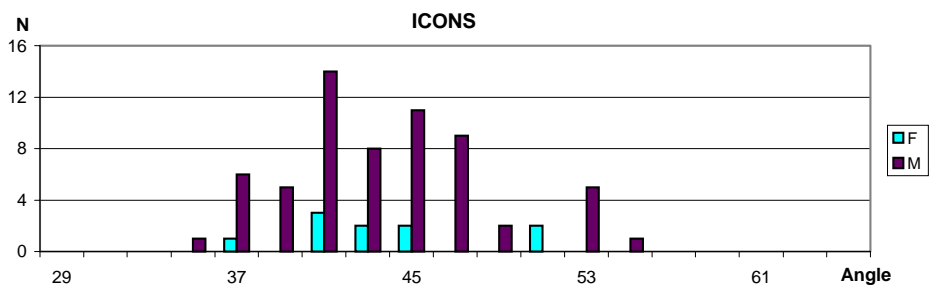

D

Fig. 1. The distribution of the eye-mouth-eye angle: (A) for the photographs of people from all over the world, (B) for the photographs of people from Lublin, (C) of most liked faces created by women and men, and (D) for the faces from icons. 
In the face schemas created by male subjects, the mean value of the angle under examination did not differ significantly from the mean angle from the photographs of those very subjects. The difference in relation to the angle from the real-life faces of women was similarly insignificant, while the variation of the angle in the schemas was distinctly greater. The results obtained in the group of female subjects were slightly different. The mean angle measured from the schemas made by them was significantly $(\mathrm{p}<0.01)$ smaller than that in the pictures of the faces of these very women, but it was insignificantly different than the mean angle from the real male faces (also in this case variation in the schemas was distinctly bigger than that in the real-life faces). Since the subjects were not instructed as to what sex the face they were to construct should be, the above result may be interpreted as an intersexual difference in the selection of the most attractive facial pattern.

Comparison of the measurements of the faces constructed by the subjects with the real-life ones revealed that the schemas of "the most attractive faces" were close to the faces most frequent in reality. The values of the angle examined were close to the mean value in arithmetical terms (cf. LANGLOIS and ROGGMAN [1990]; STRZAŁKO and KASZYCKA [1990, 1992]; KUJAWA and STRZAŁKO [1998]). Unfortunately, the sample in my research, which is not agerepresentative for the whole population, limits interpretational generalizations. The angle variation range of the faces created was bigger than the angle variation range of the real-life faces. This may be indicative of the existence of individual, supernormal releasing stimuli as well as of a tendency to exaggerate the differences spotted (like in a caricature).

The fact that the variation of the angle from the icon faces is not bigger than the variation of real-life faces may indicate that the authors of the paintings based their works on real-life experience. However, clearly smaller mean and median values of the angle may be suggestive of differences in the understanding of an ideal of sainthood and a paragon of human beauty. The preference of a face schema of an optional sex as described by the statement "I find it most attractive" may also be conditioned by individual intentions and experience. Zienkov's research indicates the objectivity of the images shown in icons [KORDYS 1991]. He noticed that out of 43 works of Old Russian art, each including a word in the form of an inscription, a roll or a book, in 41 paintings this word was located in the right part of the field of vision. This part, according to the neurophysiology of perception, is addressed to the left cerebral hemisphere housing speech centers, which process the perception material verbally. The lateralization of perception can correspond with the lateralization of other elements of composition ${ }^{\downarrow}$. The projection of, for instance, the psycho-physiological properties of a sight analyzer can take place in a state of relaxation (meditation, prayer), in which these works were being created [FRACCKIEWICZ 1999].

\footnotetext{
${ }^{1}$ Frąckiewicz W., 2001, Psychofizjologiczna estetyka malarstwa medytacyjnego, Internet, http://sokrates. umcs. lublin.pl/ frawe/mal.htm
} 
This research could be expanded by specifying preferences, differentiated not only by sex but also by age, marital status, the purpose of selection (marriage, friendship, entertainment, rivalry, hostility, cooperation, different professions, etc.). In spite of the fact that there are interesting facial attractiveness perception research techniques, still there is no method that would enable to control all factors revealed by researches. Such a method should involve a combination of efforts of representatives of various disciplines of science.

\section{Acknowledgements}

This paper benefited from the criticism and advice of the Editor and the referees.

\section{References}

AlPatov M.V., 1970, Sokrovišča russkogo iskusstva XI - XVI viekov, Avrora, Leningrad

Antonova V.I., 1966, Drevnerusskoe iskusstvo v sobranii Pavla Korina, Iskusstvo, Moskva

Bulkin V., 1982, Dionysius, Avrora, Leningrad

BREMSKE H., 1988, Ikonen, Edition Atlantis, Zürich

CARON A.J., R.F. CARON, R.C. CADWEll, S.J.

WEISS, 1973, Infant perception of structural properties of faces, Dev. Psychol., 9, 385-399

Coss R.G., 1968, The ethological command in Art, Leonardo I. Pergamon Press, Great Britain, pp. 273-287

DAVIDOFF J., 1986, The mental representation of faces: Spatial and temporal factors, Perception and Psychophysics, 6, 391-400

DERĘGOWSKI J.B., 1990, Oko i obraz, PWN, Warszawa

DRÖSCHER V.B., 1982, Reguła przetrwania, PWN, Warszawa

EIBL-EIBESFELDT I., 1986, Die Biologie des menschlichen Verhaltens, Piper, München

EIBL-EIBESFELDT I., 1987, Miłość i nienawiść, PWN, Warszawa

EtCOFF N., 2000, Przetrwaja najpiękniejsi, Wyd. CiS \& W.A.B., Warszawa
FrąCKIEWICZ W., 1998, Atrakcyjność a rysy twarzy osoby spostrzegajacej, Czasopismo Psychologiczne, 4, 288-298

FrąCKIEWICZ W., 1999, Fizjologiczna estetyka, Wszechświat, 100, 87-89

FrąCKIEWICZ W., 2000, Percepcja twarzy: schematy preferowane a rodzicielskie, Roczniki Psychologiczne, 3, 143-153

FRIDLUND A.J., 1994, Human facial expression, Academic Press, San Diego

GiBSON E.J., 1969, Principles of perceptual learning and development, Appleton Century Crafts, New York

HAIG N.D., 1986, Investigation face recognition with and image processing computer, [in:] Aspects of face processing, H.D. Ellis, M.A. Jeeves, F. Newcombe \& A. Young (eds.), Martinus Nijhoff, Dordrecht

HiRukawa T., M. Yamaguchi 1996, Effect of sexual dimorphism on human facial attractiveness, ATR HIP Research Laboratories

HÜCKSTEDT B., 1965, Experimentale Untersuchungen zum „Kindenschema”, Zeitschrift für Experimentelle und Angewandte Psychologie, 12, 421-450

KonNer M., 1982, The Tangled Wing: Biological Constraints on the Human Spirit, Harper Colophon, New York

KOESLAG J.H., 1990, Koinophilia groups sexual creatures into species, promotes stasis, and stabilizes social behavior, J. Theor. Biol., 144, 15-35

KenDRICK K.M., M.R. Hinton, K. AtKIns, 1998, Mothers determine sexual preferences, Nature, 395, 229-230

KoRDYs J., 1991, Mózg i znaki, PIW, Warszawa

Kujawa B., J. StrzaŁKo, 1998, Standard of physical attractiveness, Prz. Antropol. - Anthropol. Rev., 61, 31-48

Langlois J.H., L.A. RogGman, 1990, Attractive faces are only average, Psychol. Sci., 1, 115121

LORENZ K., 1977, Odwrotna strona zwierciadta, PIW, Warszawa

Penton-Voak I.S., D.I. Perrett, D.L. Castles, T. Koboyashi, D.M. Burt, L.K. MurRay, R. MinAmisAWA, 1999, Menstrual cycle alters face preference, Nature, 399, 741-742

Rozanova N.V., 1970, Rostovo-Suzdalskaja žiwopis' XII-XVII vekov, Izobrazitelnoe Iskusstvo, Moskva

SALKO N., 1978, Pamjatnik ovejannyj slavoj kulikowskoj bitvy, Avrora, Leningrad 
StrZaŁko J., K. Kaszycka, 1990, Atrakcyjność fizyczna - obiektywne i subiektywne sktadowe oceny, Przegląd Antropologiczny, 54, 7-17

Strzalko J., K.A. KaszyCKa, 1992, Physical attractiveness: Interpersonal and intrapersonal variability of assessments, Social Biology, 39, 170-176

SyMONS D., 1979, The Evolution of Human

Sexuality, Oxford University Press, New York
Vlek C.A.J., L.H.C. VAN DER HeIJDen, 1970, Aspects of suboptimality in multidimensional probabilistic information processing task, Acta Psychol., 34, 300-310

VORONIN N.N., 1977, Smolenskaja živopis' 12-13 vekov, Iskusstwo, Moskva

YARBUS A.L., 1965, Rol dviženija glaz w processe zrenija, Nauka, Moskva

ZuSNE L., 1970, Visual perception of form, Academic Press, New York

\section{Streszczenie}

Badania okulograficzne osób oglądających ludzką twarz wskazują, że wzrok najczęściej i najdłużej zatrzymuje się na oczach i ustach, oraz najczęściej przemieszcza się między tymi trzema punktami. Położenie oczu i ust względem siebie można określić za pomoca jednej liczby, która jest miarą kąta o wierzchołku w środku ust i ramionach przechodzących przez środki źrenic. Kąt ten zmierzono na fotografiach osób z całego świata oraz grupy z Lublina. Badani z Lublina sporządzali następnie, za pomocą trzech punktów, schematy twarzy o najatrakcyjniejszym dla nich rozmieszczeniu oczu i ust. Zmierzono ten kąt na uzyskanych schematach, a dodatkowo na twarzach z ikon. Schematy najbardziej atrakcyjnych - zdaniem badanych - twarzy charakteryzowały się kątem zbliżonym do średniego ze zdjęć, a istotnie większym od kąta z ikon. 